Article

\title{
Land Application-Based Olive Mill Wastewater Management
}

\author{
Iosif Kapellakis ${ }^{1,3, *}$, Vasileios A. Tzanakakis ${ }^{2}$ and Andreas N. Angelakis ${ }^{3}$ \\ 1 Kapellakis Technical and Real Estate Firm, Venerato Palianis 70011, Greece \\ 2 Region of Crete, Directorate of Agricultural Economy, Iraklion 71201, Greece; \\ E-Mail: vetzanakakis@gmail.com \\ 3 National Agricultural Research Foundation (N.AG.RE.F.), Institute of Iraklion, \\ Iraklion 71307, Greece; E-Mail: info@a-angelakis.gr \\ * Author to whom correspondence should be addressed; E-Mail: iosif1976@gmail.com or \\ kapellakis@teemail.gr; Tel.: +30-281-079-1948; Fax: +30-281-500-3399.
}

Academic Editor: Irene Xagoraraki

Received: 10 October 2014 / Accepted: 13 January 2015 / Published: 22 January 2015

\begin{abstract}
Land application of olive mill wastewater (OMW) is considered a promising low-cost practice for olive-oil producing countries. The objectives of this work were to investigate: (i) OMW treatment potential of a land treatment system (LTS), planted with a E. camaldulensis species, regarding N, P, C, and phenols; (ii) the effects of OMW on chemical properties of soil and soil solution characteristics; and (iii) the performance of E. camaldulensis in terms of biomass production and $\mathrm{N}$ and $\mathrm{P}$ recovery. E. camaldulensis received OMW for two growing seasons at rates based on maximum organic loading. These rates were almost equivalent to the reference evapotranspiration of the area. Soil solution and soil samples were collected from three different depths $(15,30$ and $60 \mathrm{~cm})$ at specified time intervals. -Also, samples of plant tissues were collected at the end of application periods. OMW land application resulted in significant reduction in inorganic and organic constituents of OMW. At $15 \mathrm{~cm}$ of soil profile, the average removal of COD, TKN, $\mathrm{NH}_{4}{ }^{+}-\mathrm{N}$, TP, In-P, and total phenols approached $93 \%, 86 \%, 70 \%, 86 \%, 82 \%$, and $85 \%$, respectively, while an increase in soil depth $(30$ and $60 \mathrm{~cm}$ ) did not improve significantly treatment efficiency. Furthermore, OMW increased soil organic matter (SOM), total kjeldahl nitrogen (TKN), and available P, particularly in the upper soil layer. In contrast, low inorganic $\mathrm{N}$ content was observed in the soil throughout the study period caused probably by increased competition among soil microorganisms induced by the organic substrate supply and high $\mathrm{C} / \mathrm{N}$ ratio. Also, electrical conductivity (EC) and SAR
\end{abstract}


increased by OMW addition, but at levels that may do not pose severe risk for soil texture. Enhancement of soil fertility due to OMW application sustained eucalyptus trees and provided remarkable biomass yield. In conclusion, land application of OMW has a great potential for organic matter and phenol assimilation and can be effectively used for OMW detoxification.

Keywords: olive mill wastewater; E. camaldulensis; irrigation; land treatment; land application; biomass production; nutrient uptake; soil impacts; organic matter; phenols; salinity

\section{Introduction}

Olive mill wastewater (OMW) is the liquid by-product generated mainly in three-phase (olive oil-OMW-pomace) olive mills during olive oil production. Around $6 \times 10^{6} \mathrm{~m}^{3}$ of OMW is produced worldwide at a short period, between November and March, of which $98 \%$ is produced in the Mediterranean basin [1]. In areas that have not yet adopted the newer two-phase extraction technique (olive oil-liquid pomace) the most common adopted practices to manage OMW remain the storage in evaporation ponds [2] and the direct application onto land [3]. Spreading of OMW onto land is considered a promising low-cost practice since most of the Mediterranean olive-oil producing countries suffer from water deficiency and deterioration of terrestrial and aquatic environment $[3,4]$. Italy, Portugal, and Catalonia have already regulated land application of OMW allowing, however, low application rates in order to prevent toxicity phenomena in soil and crops [3,5].

Earlier study demonstrate the high potential of soil in terms of the assimilation and removal of both inorganic and organic OMW constituents at application rates up to $1000 \mathrm{~mm} / \mathrm{year}$ [6]. This is efficiency due to presence of easily decomposable organic compounds in OMW that stimulate soil microorganisms and their activities [7,8] inducing decomposition and mineralization processes. In addition to biodegradation part of the applied organic substrate and nutrients may be retained into the soil matrix $[9,10]$, leading to enhancement of soil fertility $[6,7,11,12]$. Also, OMW application may cause alterations in soil biological properties [7,13-16] associated with the changing nutrient availabilities and/or toxicity phenomena. With regard to physical properties of soil, there is evidence of changes due to OMW application, but the results so far are contradictory [6,17,18]. Several factors are considered important to the response of soil to OMW application including organic substrate, soil-climatic conditions, management practices, and vegetation. With regard to vegetation, recent studies have evidenced that plant species, via litter decomposition and rhizodeposition, affect soil physicochemical properties, soil microbial communities, and $\mathrm{C}$ and $\mathrm{N}$ turnover rates [19-22]. Given the high organic loading in OMW and the presence of vegetation the optimization of OMW application rates and treatment potential — still remains a challenge.

To date available data on OMW land application, particularly for eucalyptus species is limited. These species are widely used in land application schemes due to several desirable attributes, such as adaptability to soil salinity, treatment potential, and biomass production [23], however, their performance in cases of OMW application remains unknown. Moreover, despite the plethora of work dealing with OMW effect on soil properties, little information is available with regard the distinct 
effect of OMW on the quality and characteristics of soil solution. The composition of this fraction is critical as it can be easily moved through soil profile and threaten underlying and surface waters. Thus, the objectives of this work were to investigate: (i) treatment potential of a land application scheme planted with E. camaldulensis species especially with regard to N, P, C, and phenols; (ii) the effects on soil chemical properties and soil solution characteristics; and (iii) the performance of E. camaldulensis in terms of biomass production and nutrient recovery. The knowledge provided is expected to contribute towards a better understanding of the capacity of land treatment systems (LTS) to assimilate OMW constituents, optimization of their operation, and elimination of the environmental risk.

\section{Materials and Methods}

The study was carried out at the experimental field of National Agricultural Research Foundation at Skalani village, located $10 \mathrm{~km}$ south of Iraklio City, Greece. The map reference co-ordinates of the experimental field are latitude $35^{\circ} 16^{\prime} 51^{\prime \prime} \mathrm{N}$ and longitude $25^{\circ} 10^{\prime} 51^{\prime \prime} \mathrm{E}$, and the elevation is $233 \mathrm{~m}$ a.s.l. The experimental field, the soil sampling and analysis, and the biomass production are discussed as follows.

A pilot LTS was established in April 2003, including 40 E. camaldulensis seedlings planted at two double rows of 20 seedlings each. The seedlings were planted at distances of $1 \mathrm{~m}$ within and between rows in each of the double row. The distance between double rows was $1 \mathrm{~m}$. The total covered area was $44 \mathrm{~m}^{2}$. The soil was conventionally tilled before planting the E. camaldulensis trees. The LTS operated from June to October 2003, and from April to October 2004. OMW from a nearby olive mill was stored in a retention pond and applied through furrow irrigation to the LTS. Olive mill wastewater was applied at such rates so that the organic load did not exceed $500 \mathrm{~kg} \mathrm{BOD} /$ ha day, the highest organic loading rate recommended for LTS [24]. Based on the COD/BOD ratio of the applied wastewater, which is approximately 2.5 , the average loading of LTS was approximately $1250 \mathrm{~kg} \mathrm{COD} / \mathrm{ha} \cdot \mathrm{d}$. Effluent was applied approximately on fortnightly cycles to provide adequate time for organic matter degradation and to avoid clogging of soil pores. The hydraulic load applied in the field, was derived from the following Equation:

$$
\frac{V \cdot C}{T \cdot A} \leq 1250 \frac{\mathrm{kgCOD}}{\mathrm{ha} \cdot \mathrm{d}}
$$

where, V: Loading volume $\left(\mathrm{m}^{3}\right)$; C: Influent COD concentration $(\mathrm{mg} / \mathrm{L}) ; \mathrm{T}$ : Time intervals (typically $15 \mathrm{~d})$; A: Area of the field (0.0044 ha).

The reference evapotranspiration (ETo) was calculated using Cropwat 8.0 software [25], based on FAO Penman-Monteith method. The soil of the study area was clay loam with high calcium content (55\% $\left.\mathrm{CaCO}_{3}\right)$; $\mathrm{pH}$ : 7.58; electrical conductivity (ECsp): $0.55 \mathrm{dS} / \mathrm{m}$; organic matter content: $0.79 \%$; total kjeldahl nitrogen (TKN): 0.049\%; and Olsen-P: 14 ppm. OMW samples before the fortnightly application were being collected and analyzed for $\mathrm{pH}, \mathrm{EC}, \mathrm{COD}, \mathrm{TKN}, \mathrm{NH}_{4}{ }^{+}-\mathrm{N}, \mathrm{NO}_{3}{ }^{-} \mathrm{N}$, TP, inorganic $\mathrm{P}$ (In-P), and total phenols. The average composition of OMW applied to LTS is presented in Table 1. During the study soil solution samples were collected at $15 \mathrm{~cm}, 30 \mathrm{~cm}$, and $60 \mathrm{~cm}$ soil depth with soil water samplers (Soil Moisture Equipment Corp. model 1920F1124-B0,5 M2; Santa Barbara, CA, USA) $24 \mathrm{~h}$ after OMW application, to allow the applied effluent to equilibrate with soil and were analyzed for the parameters previously reported. The soil solution samplers were installed at the center of a double row of the LTS, and were stabilized with a thin layer of betonite. Tensiometers were installed at 
depths of 30 and $60 \mathrm{~cm}$ to provide indications of soil moisture during the OMW application period. Preparation and analyses of the samples was undertaken according to the Standard Methods for the Examination of Water and Wastewater [26]. Total phenols were assessed according to the Folin-Ciocalteu method [27]. Soil samples were collected in April 2003 (beginning of the study), in October 2003 (end of first year application), and in October 2004 (end of the experiment) from 0 to 15, 15 to 30, 30 to 45, and 45 to $60 \mathrm{~cm}$ soil depth. Samples were also collected from 60 to $75 \mathrm{~cm}$ soil layer in October 2003 and 2004. Samples were analyzed for soil organic matter (SOM), TKN, available P (Olsen-P), pH, ECsp, $\mathrm{Ca}^{2+}, \mathrm{Mg}^{2+}$, and SAR according to Methods of Soil Analysis [28].

Table 1. Composition of olive mill wastewater (OMW) (average values) in the retention pond (in $\mathrm{mg} / \mathrm{L} ; \mathrm{pH}$ is unitless; $\mathrm{EC}$ in $\mathrm{dS} / \mathrm{m}$ ). In parenthesis is shown the standard error.

\begin{tabular}{cc}
\hline Parameters & Applied OMW \\
\hline $\mathrm{pH}$ & $6.22(0.28)$ \\
$\mathrm{EC}$ & $7.15(0.25)$ \\
$\mathrm{COD}$ & $21,862(2,92)$ \\
$\mathrm{NH}_{4}^{+}-\mathrm{N}$ & $17.61(2.48)$ \\
$\mathrm{TKN}$ & $167.8(29.16)$ \\
$\mathrm{Org}_{-} \mathrm{N}$ & $150.2(22.16)$ \\
$\mathrm{NO}_{3}{ }^{-}$ & $2.11(0.04)$ \\
$\mathrm{In}-\mathrm{P}$ & $21.5(3.65)$ \\
$\mathrm{TP}$ & $63.87(16.89)$ \\
Total phenols & $1,386(151.67)$ \\
\hline
\end{tabular}

Biomass accumulation was assessed in October 2003 and 2004. In October 2003 three representative trees were harvested and separated into individual organs. Dry weight of total biomass was assessed after drying representative sub-samples at $65{ }^{\circ} \mathrm{C}$ to constant weight. Then dry samples were grounded to pass through a 1-mm screen and stored for elemental analysis. Similarly, at the end of the second experimental period, seven representative trees were harvested and the dry weight and nutrient tissue concentrations were assessed similar to the previous growing season. In the present study, water use efficiency (WUE), nutrient used efficiency for nitrogen (NUE-N) and phosphorus (NUE-P) were determined by taking into account biomass yield, OMW loading, and the amounts of $\mathrm{N}$ and $\mathrm{P}$ recovered, respectively. Specifically, WUE of plant species was estimated by dividing the dry weight of the produced hypergeous biomass with the applied amount of effluent. NUE-N and NUE-P were determined by hypergeous biomass divided by the amount of $\mathrm{N}$ and $\mathrm{P}$ recovered, respectively. Nutrient removal refers to the percentage of the applied, via OMW application, nutrient that assimilated in plant biomass. Analysis of variance (ANOVA) was performed to assess the effect of soil depth on the parameters examined using SPSS software [29].

\section{Results}

\subsection{Storage of Olive Mill Wastewater}

Storage in retention pond affected the physico-chemical properties of OMW. The $\mathrm{pH}$ of the raw OMW increased from 5.04 in April to 7.47 in the middle of October 2004. The EC also showed an 
increasing trend from the initial value of $5.75 \mathrm{dS} / \mathrm{m}$ to $8.00 \mathrm{dS} / \mathrm{m}$ in October, due to the high ET values prevailing in the study area and the concentration of the effluent volume (Figure 1). The degradation of organic compounds and the release of electrolytes may have also contributed to this increase. In contrast, COD concentration decreased from the initial values of $30,000 \mathrm{mg} / \mathrm{L}$ to $5200 \mathrm{mg} / \mathrm{L}$ in September, due to the sedimentation of organic matter present in particulate form and the biodegradation of organic compounds. Decreasing trends were also observed for total phenols concentration from $2600 \mathrm{mg} / \mathrm{L}$ to $1200 \mathrm{mg} / \mathrm{L}$, in accordance with previous study [4], attributable to microbiota activity present in OMW [30,31]. Significant fluctuations were observed in organic-N concentration, throughout the experimental period without a clear trend. TP concentration in raw OMW followed a decreasing trend over time. In April 2004, TP concentration was $129.01 \mathrm{mg} / \mathrm{L}$ and by the end of the experiment, it was $18.67 \mathrm{mg} / \mathrm{L}$. Composition of OMW applied in the field is shown in Table 1.

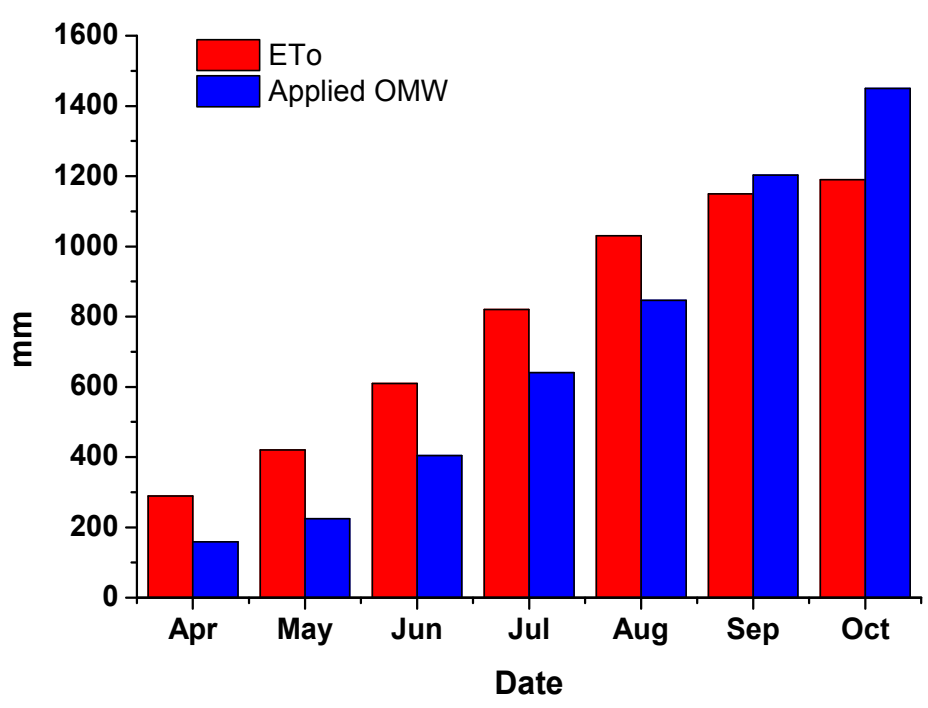

Figure 1. Reference evapotranspiration (ETo) and applied OMW during 2004 application period.

\subsection{Applied Hydraulic and Nutrient Loads}

The cumulative OMW and $\mathrm{N}$ and $\mathrm{P}$ loads applied at LTS are shown in Table 2. Variations in cumulative hydraulic load and reference evapotranspiration $\left(\mathrm{ET}_{\mathrm{o}}\right)$ of the area throughout the experimental period are also shown in Figure 1. The OMW applied at a relatively stable rate throughout the second application period in contrast to $\mathrm{ET}_{\mathrm{o}}$ rate, which showed a gradual decline particularly from August to the end of the season due to lower temperatures. As a result the hydraulic load of OMW exceeded the ETo at the beginning of October (Figure 1).

Table 2. Cumulative hydraulic, nitrogen, and phosphorus loads at the end of 2003 and 2004, applied at E. camaldulensis trees.

\begin{tabular}{cccc}
\hline Year & Hydraulic Load $(\mathbf{m m})$ & Nitrogen $\mathbf{( k g} / \mathbf{h a})$ & Phosphorus $\mathbf{( k g / h a )}$ \\
\hline 2003 & 318.18 & 531.36 & 176.59 \\
2004 & 1767.97 & 2952.50 & 981.22 \\
\hline
\end{tabular}




\subsection{Soil Solution Samples}

The data of the soil solution samples regards the period April to October 2004. pH values in soil solution samples increased gradually until late September and then almost leveled off by the end of the experiment (Figure 2a). Lower $\mathrm{pH}$ values were observed with increasing soil depth and at 20 September soil $\mathrm{pH}$ was 7.65 at $15 \mathrm{~cm}, 7.45$ at $30 \mathrm{~cm}$, and 7.25 at $60 \mathrm{~cm}$ soil depth.

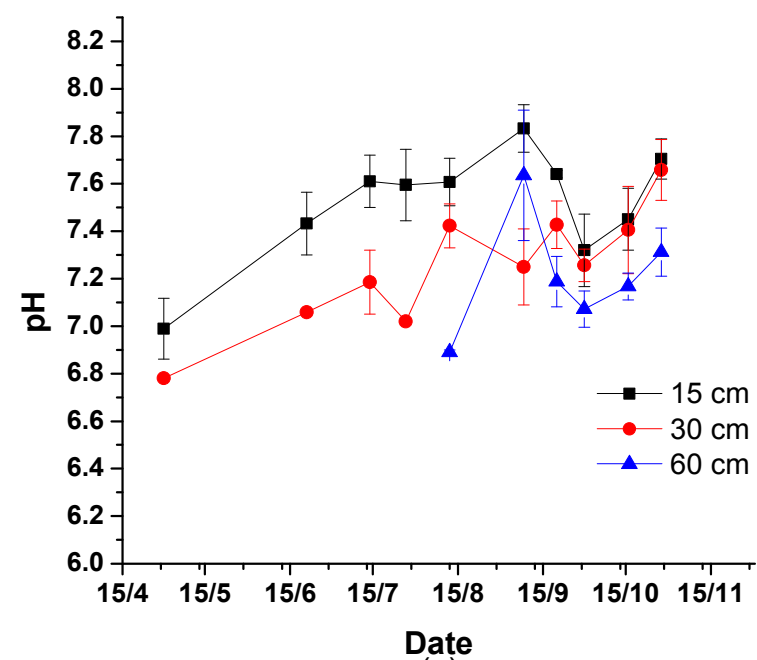

(a)

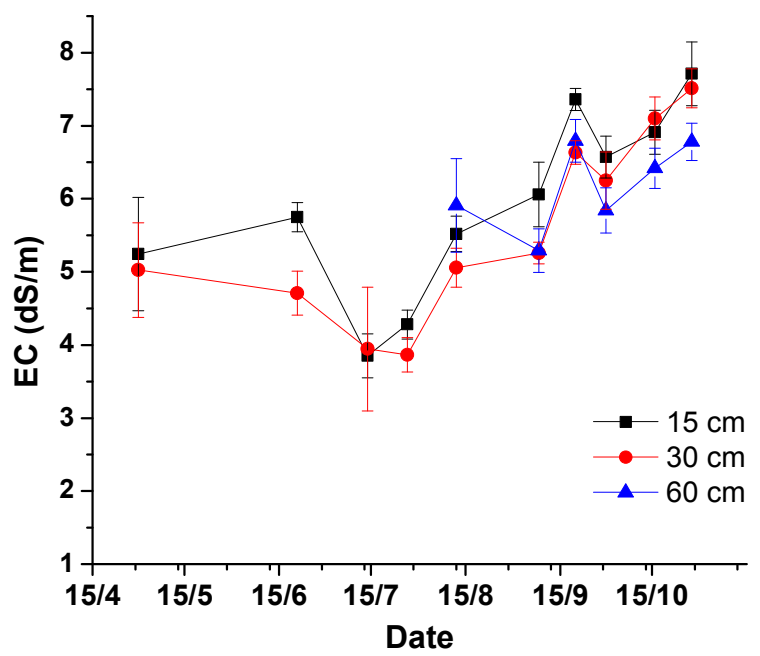

(b)

Figure 2. Values in soil solution of (a) $\mathrm{Ph}$ and (b) EC during the second application period.

EC in soil solution samples had an increasing trend throughout the OMW application period reaching at $7.1 \mathrm{dS} / \mathrm{m}$ at the end of October, 2004 (Figure 2b). Deeper soil layers tended to have lower EC values, but the differences were proved not statistically significant. Variations in COD concentration of the soil solution samples were observed during the second application period (2004), showing an decreasing trend from $5000 \mathrm{mg} / \mathrm{L}$ at the beginning of the period to $200 \mathrm{mg} / \mathrm{L}$ toward the end of September (Figure 3a). The removal of organic matter (represented here as COD) occurred at the upper $15 \mathrm{~cm}$ of the soil profile (93\%) and no further reduction was observed with increasing soil depth. Total phenols concentration in the soil solution samples followed a similar trend with COD, with average reduction at $86 \%$ at $15 \mathrm{~cm}$, while an increase was observed after mid-September. An increase in soil depth did not contribute further to reduction of phenols in the soil solution (Figure $3 b$ ).

With regard to TP in soil solution samples, variations were observed throughout the study period between 20 and $1 \mathrm{mg} / \mathrm{L}$, at all soil profiles (Figure 3f).

Similarly to COD, TKN, and $\mathrm{NH}_{4}{ }^{+}-\mathrm{N}$ concentrations significantly decreased at the $0-15 \mathrm{~cm}$ layer (86\% and $70 \%$, respectively) and no further reduction was observed with the increase of soil depth (Figure 3c,d). Their values in soil solution varied during OMW application without showing a characteristic pattern. With regard to $\mathrm{NO}_{3}{ }^{-}-\mathrm{N}$ concentration, low values were observed in soil solution samples during the examined period, below the level of $2.5 \mathrm{mg} / \mathrm{L}$, showing a decreasing trend with the season's progress (Figure 3e). 


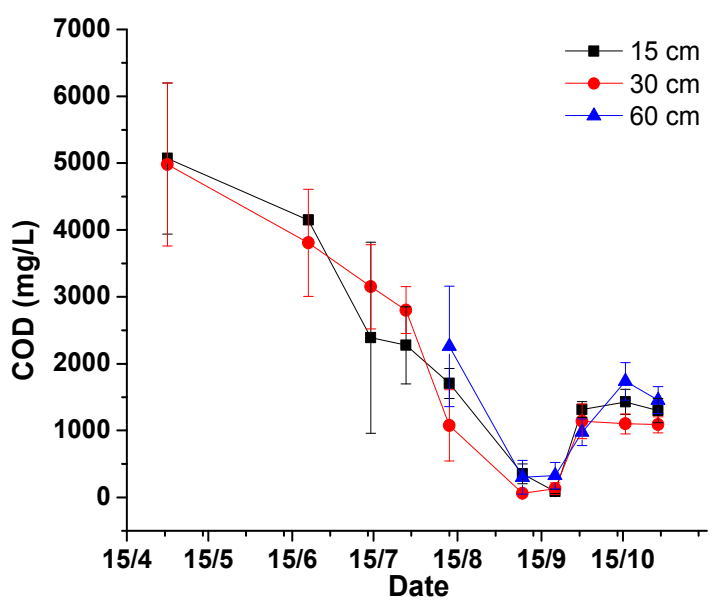

(a)

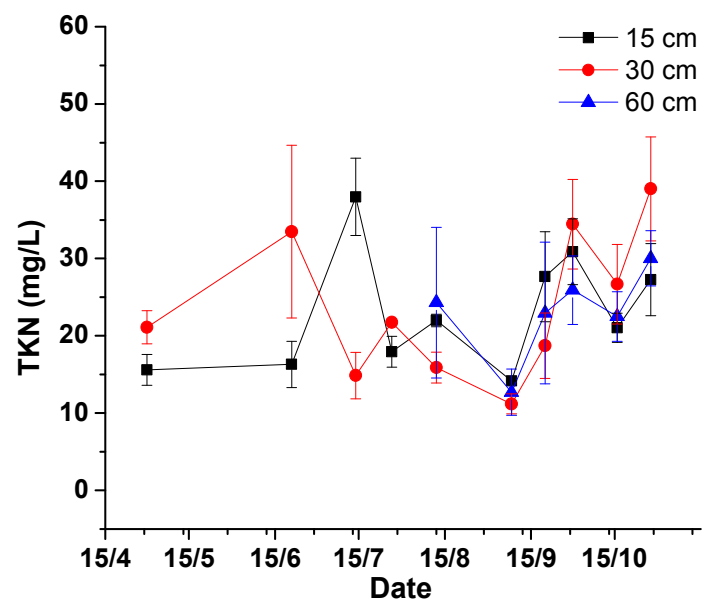

(c)

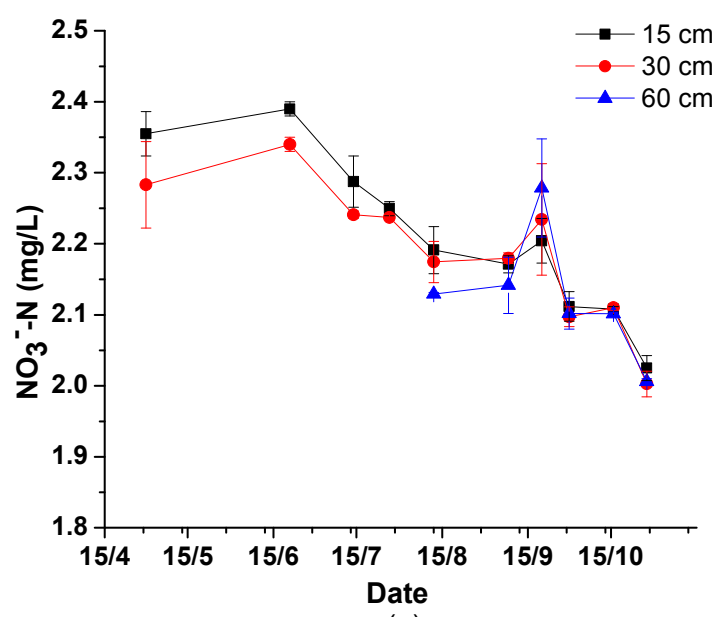

(e)

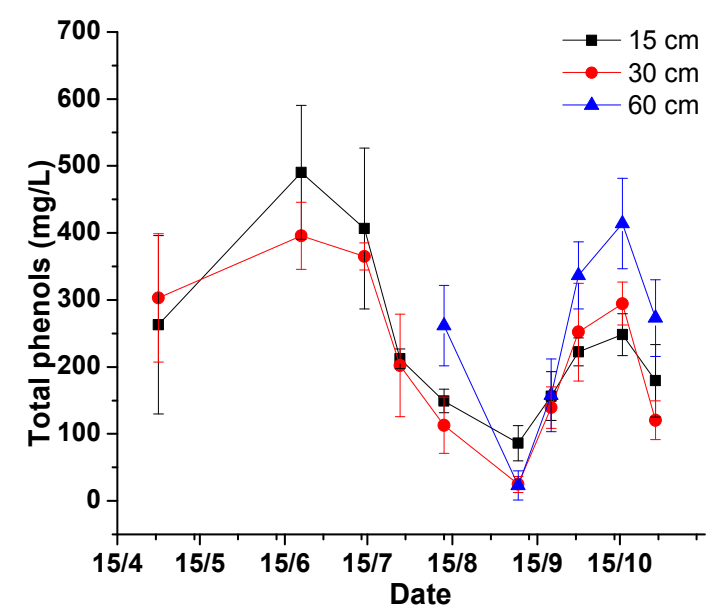

(b)

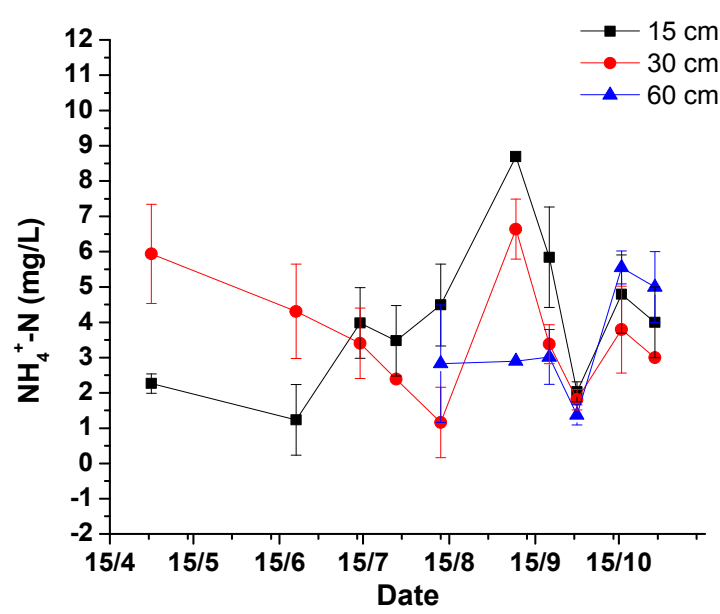

(d)

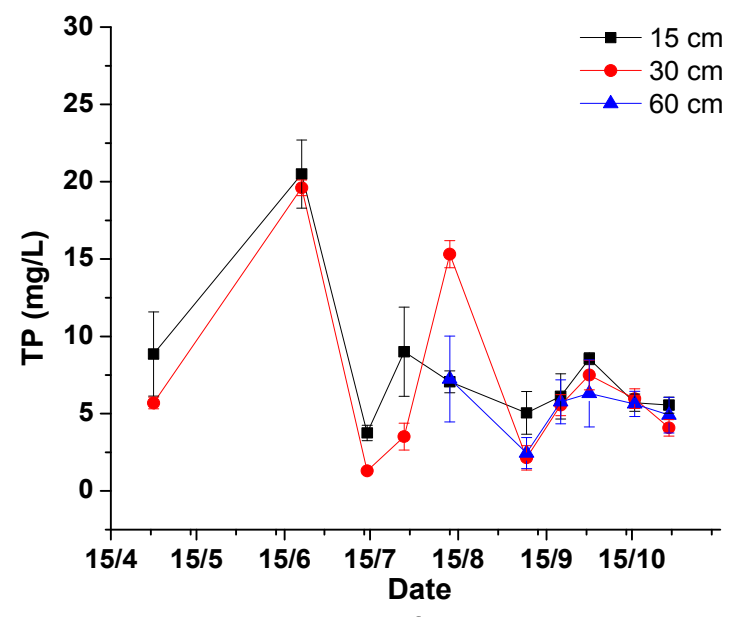

(f)

Figure 3. Concentration in soil solution of (a) COD; (b) total phenols; (c) total kjeldahl nitrogen (TKN); (d) $\mathrm{NH}_{4}{ }^{+}-\mathrm{N}$; (e) $\mathrm{NO}_{3}{ }^{-}-\mathrm{N}$; and (f) total phosphorus (TP). 


\subsection{Soil Samples}

OMW application gradually increased SOM mainly at the upper soil layers. A slight increase in SOM occurred only at the first $30 \mathrm{~cm}$ of soil depth in 2003, but the following year SOM increased up to 10 -fold at the $0-15 \mathrm{~cm}$ soil depth (Figure 4a). A similar to SOM trend was observed in TKN; approximately 2.5 -fold higher than the initial value at the end of the study period in the $0-15 \mathrm{~cm}$ and 15-30 cm soil layers (Figure 4b). OMW application increased substantially the concentration of available $\mathrm{P}$ in the soil. This effect was stronger at the surface soil layer and showed a decreasing trend toward the deeper soil layers (Figure 4c).
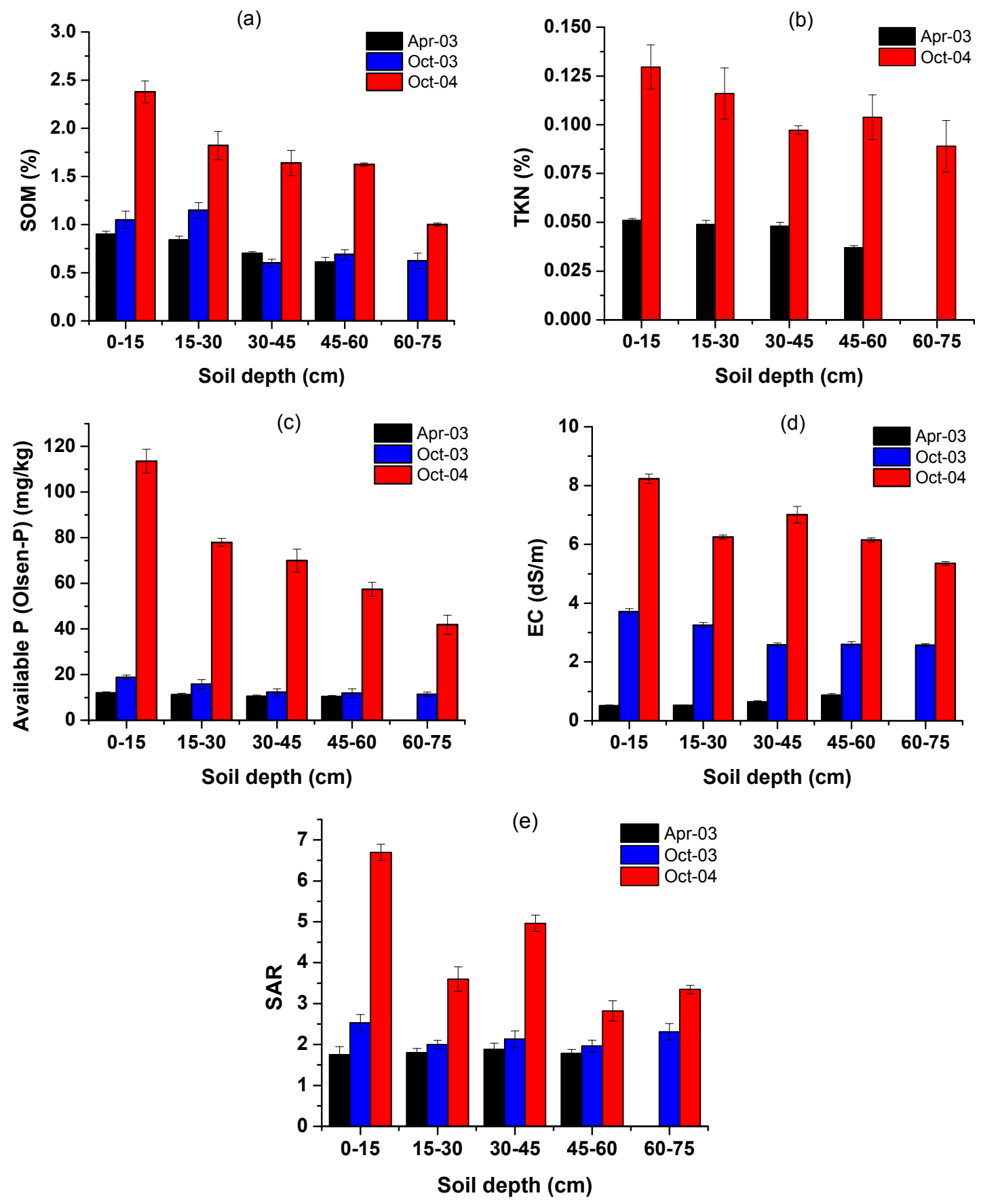

Figure 4. Concentrations in soil of (a) soil organic matter (SOM); (b) TKN (\%); (c) TP; (d) electrical conductivity (EC); and (e) SAR. 
The OMW application resulted in gradual increase of EC throughout the two application periods, as shown in Figure 4d, associated with the accumulation of salts in the soil. SAR values followed a similar pattern with that of EC and increased during OMW application periods, from 1.7 at the beginning of the first period (April 2003) to 6.7 at the end of the experiment (October 2004) in $0-15 \mathrm{~cm}$ of the soil depth resulting from gradual domination of $\mathrm{Na}^{+}$over the $\mathrm{Ca}^{2+}$ and $\mathrm{Mg}^{2+}$ (Figure 4e).

\subsection{Biomass Production and Nutrient Recovery}

The total hypergeous biomass yield of eucalyptus plantation and allocation to different plant organs is shown in Table 3. The $\mathrm{N}$ content in trunk, shoots, and leaves in eucalyptus trees was $1.17 \%, 1.37 \%$, and $4.08 \%$, respectively, in 2003 and $0.55 \%, 0.58 \%$, and $2.04 \%$ in the following year. $\mathrm{P}$ content in plant organs was $0.09 \%$ for trunk $0.09 \%$ for shoots, and $0.25 \%$ for leaves in 2003 and $0.07 \%, 0.09 \%$, and $0.15 \%$, respectively, in 2004 . The higher plant nutrient tissue contents in the first growing season are due to the higher portion of juvenile growth which is characterized by a greater content of nutrients.

Table 3. Cumulative biomass production, accumulated $\mathrm{N}$ and $\mathrm{P}$ (and removal percentage), nutrient used efficiency for nitrogen (NUE-N), nutrient used efficiency for phosphorus (NUE-P), and water use efficiency (WUE) in different plant organs of E. camaldulensis $(\mathrm{Kg} / \mathrm{ha})$ trees received OMW at the end of the two growing seasons (2003 and 2004). In parenthesis is shown the standard error.

\begin{tabular}{ccccccc}
\hline Parameter & Year & Trunk & Shoots & Leaves & Total & Removal (\%) \\
\hline Biomass yield & 2003 & $1,676(201)$ & $993(138)$ & $2,500(358)$ & $5,170(694)$ & - \\
$(\mathrm{kg} / \mathrm{ha})$ & 2004 & $10,389(1,078)$ & $5,389(475)$ & $6,993(930)$ & $22,771(2,316)$ & - \\
\hline \multirow{2}{*}{$\mathrm{N}(\mathrm{kg} / \mathrm{ha})$} & 2003 & $19.64(2.7)$ & $13.77(2.5)$ & $101.20(12.7)$ & $134.61(17.8)$ & 25.33 \\
& 2004 & $51.89(7.3)$ & $29.53(5.1)$ & $134.74(27.6)$ & $216.16(38.2)$ & 7.32 \\
\hline \multirow{2}{*}{$\mathrm{P}(\mathrm{kg} / \mathrm{ha})$} & 2003 & $1.51(0.2)$ & $0.92(0.2)$ & $6.02(0.6)$ & $8.45(0.9)$ & 4.79 \\
\hline \multirow{2}{*}{$\mathrm{NUE-N}(\mathrm{kg} / \mathrm{kg})$} & 2004 & $6.81(1.4)$ & $4.80(0.9)$ & $10.64(2.4)$ & $22.26(4.5)$ & 2.27 \\
\hline \multirow{2}{*}{ NUE-P $(\mathrm{kg} / \mathrm{kg})$} & 2003 & $85.80(3.9)$ & $73.28(3.3)$ & $24.58(0.9)$ & $38.38(1.1)$ & - \\
\hline \multirow{2}{*}{ WUE $(\mathrm{g} / \mathrm{kg})$} & 2004 & $185.07(7.8)$ & $194.83(30.7)$ & $51.39(4.1)$ & $102.97(5.6)$ & - \\
\hline & 2004 & $1,980.96(409.7)$ & $1,168.09(119.6)$ & $680.89(48.4)$ & $1,132.40(119.7)$ & - \\
\hline
\end{tabular}

Eucalyptus trees accumulated in $134.61 \mathrm{kgN} / \mathrm{ha}$ and $8.63 \mathrm{kgP} / \mathrm{ha}$ in hypergeous biomass in 2003 and $216 \mathrm{kgN} / \mathrm{ha}$ and $22.6 \mathrm{kgP} / \mathrm{ha}$ after the following growing season (2004) (Table 3). Plant organs had different contribution to total nutrients accumulation in hypergeous biomass due to their differences in nutrients content and the amount of biomass produced. The distribution of $\mathrm{N}$ and $\mathrm{P}$ to plant organs is shown in Table 3. Taking into account the applied $\mathrm{N}$ and $\mathrm{P}$ loads, eucalyptus trees accumulated the $25 \%$ of the applied $\mathrm{N}$ and $5 \%$ of the applied $\mathrm{P}$ at the end of two growing seasons. NUE-N and NUE-P increased significantly during OMW application, as shown in Table 3. In contrast, WUE had lower value at the end of second growing season period compared to that of 2003. 


\section{Discussion}

Soil planted with eucalyptus species showed great assimilation potential for the organic C, particularly at the first $15 \mathrm{~cm}$ of soil profile, which is consistent with the presence of labile organic compounds in the OMW. Such an organic fraction, having also high $\mathrm{C} / \mathrm{N}$ ratio, stimulates the indigenous heterotrophic microorganisms inducing organic matter mineralization [7,13,15]. COD concentration in soil solution decreased gradually until late the second application period (September) probably following the pattern of COD content in the applied OMW. It is also possible a gradual adaptation to OMW application for soil microbial communities. Land application of OMW enhanced SOM, in agreement with the findings of previous studies [3,6], an effect that was observed throughout the examined soil profile (up to $75 \mathrm{~cm}$ soil depth). This effect is attributed to the presence of recalcitrant compounds in OMW and/or the effect of certain retention mechanisms, such as the adsorption onto minerals and/or occlusion in clay microstructures that are inaccessible to decomposers and enzymes $[9,10]$. Our finding indicates the great potential of OMW in terms of the organic matter assimilation and increase of SOM content in the soil, an effect with great importance for the olive-oil producing countries in most of which soils suffer from low organic matter content and gradual degradation as a result of the favorable environmental conditions and thee applied agronomic practices.

Phenols in soil solution followed almost a similar pattern with that of SOM. Their reduction occurred mainly at the first $15 \mathrm{~cm}$ of soil, following in parallel a decreasing trend until late August. Several factors are responsible for the depletion of soluble phenols in the soil, including microbial degradation, polymerization to recalcitrant high-molecular mass polyphenols, incorporation into the SOM, and adsorption into soil particles. In this study, the high removal rates observed from the beginning of OMW application provide evidence of the effective adsorption of phenols onto clay minerals, induced by the clay-rich experimental soil [32]. Moreover, these rates continued until late August probably following the decreasing trend of phenol concentration in the storage pond and the stimulated phenols biodegradation processes. Previous studies report changes in the composition of soil microorganisms [7,15,33] and enzymes activities [13,34] involved in phenol degradation, indicating that OMW may favor soil microorganisms and activities specialized to degradation of phenolic compounds. Similarly to our study, under field conditions, it has been reported significant reduction of phenols, described by a first order kinetics with the constant value $(\mathrm{K})$ to range from -0.014 to -0.018 per day [3]. However, these values correspond to half-life time of about 15 to 32 days which are considerably lower to the removal rates observed in the present study in which 15-day interval resulted in approximately 80\% removal. Differences in environmental conditions prevailing between study areas and the presence of vegetation may explain this variation. Surprisingly, phenols increased toward the end of the study, similarly with COD pattern, which is probably associated with less favorable environmental conditions that possibly retarded mineralization processes.

Land application of OMW resulted in significant reduction in TKN, as indicated by low TKN content in soil solution, effect that is largely attributed to organic $\mathrm{N}$ mineralization induced by stimulated heterotrophic microorganisms. The increase in TKN content in soil samples observed at the end of the experimental period suggest that a part of the organic $\mathrm{N}$ remained in the soil, consistent with SOM findings and the findings of previous study [6]. Despite the effective organic $\mathrm{N}$ mineralization $\mathrm{NH}_{4}{ }^{+}-\mathrm{N}$ content in solution did not increase throughout the OMW application period. This is probably 
due to intense microbial immobilization caused by increased competition for $\mathrm{N}$ among soil microorganisms [34]. The low levels of nitrates observed in this study support further this hypothesis. Similar result regarding nitrates is reported by a recent microcosm study attributing it to potential inhibition of nitrifying microorganisms by low mineral $\mathrm{N}$ availability, caused by increased inorganic $\mathrm{N}$ microbial immobilization, rather than toxicity [34]. With regard to $\mathrm{P}$, it had also a remarkable reduction through soil infiltration due to adsorption and precipitation phenomena induced by the clay-rich and calcareous soil of the present study.

Application of OMW increased substantially soil salinity at levels which may have affected crop performance and microbial activity. However, in terms of the former, this might be unexpected considering great adaptability and tolerance of eucalyptus species to soil salinity [23]. In addition, rainfall during winter period leached effectively salts accumulated during irrigation with effluent of approximately $2 \mathrm{dS} / \mathrm{m}$ electrical conductivity- [35]. Increase of SAR throughout the experimental period does not also imply adverse impact on structure of soil, given the increased EC values in the soil. Likewise, in a three year OMW treated soil no sodification hazard was observed despite the increase in SAR values [6]. In terms of the effect of salinity on soil microorganisms, adverse effects are suggested by previous studies, indicated by decreases in soil respiration, microbial biomass $\mathrm{C}$, and activities of the exocellular enzymes, such as $\beta$-glucosidase, alkaline phosphatase and arylsulphatase [36,37]. Moreover, there are reports for shifts in microbial community composition associated with changes in status of salinity in the soil $[38,39]$. However, in this study only chemical parameters were examined and the response of soil microorganisms to OMW additions and/or to eucalyptus activity remains questionable.

Short rotation coppice is a practice highly compatible with the concept of land treatment because it stimulates nutrient recycling, minimizes environmental risks, and results to economic benefits. In previous study dealing with meatwork irrigation on different Eucalyptus spp, E. globules produced $35 \mathrm{t} / \mathrm{ha}$ at the age of two years [40], which is approximately 50\% higher than the yield of the present study. Even higher dry biomass is reported for 24 months old E. camaldulensis seedlings, grown under municipal effluent application at rates equivalent to evapotranspiration needs, at $7000 \mathrm{~g}$ per seedling [41]. This yield corresponds to about $60 \mathrm{t} / \mathrm{ha}$, when the spacing of the present study is considered. In contrast, E. camaldulensis seedlings irrigated for 18 months with industrial effluent achieved extremely low hypergeous biomass at yield 300 per seedling [42]. Finally, in an adjacent field of the present study, biomass produced by E. camaldulensis irrigated with municipal effluent at ET rates reached at $28.4 \mathrm{t} / \mathrm{ha}$ at the end of the second application period [43]. The lower yield obtained in the present study compared to the previous mentioned study is probably due to water deficit developed early in the growing season (Figure 1) and to low inorganic $\mathrm{N}$ availability rather than to a toxic effect of OMW. Phytotoxicity is negatively related to plant age and mainly occur at stage of seed break $[4,16]$. Exposure to phenol concentration of up to $250 \mathrm{mg} / \mathrm{L}$ did not induce toxicity development of $S$. viminalis seedlings grown hydroponically [44].

Plant uptake is an important pathway for nutrients removal in LTS. In the present study only a minor portion of the applied $\mathrm{N}$ assimilated in plant biomass, lower than $10 \%$ of applied loads, but this is primarily due to high nutrient loadings (Table 2) and less to nutrient assimilation potential of eucalyptus plantation. Similar findings to our study in terms of nutrient uptake potential of eucalyptus plantations have been reported by a previous study [40]. On the contrary, lower $\mathrm{N}$ and $\mathrm{P}$ uptake potential was achieved by E. camaldulensis in the present study compared to that of the adjacent field 
study [43], at 30\% and $42 \%$, respectively, attributed to lower biomass yield and $\mathrm{N}$ and $\mathrm{P}$ contents in plant tissues probably caused by low inorganic $\mathrm{N}$ availability in the soil.

\section{Conclusions}

Based on the findings of the present study we can conclude:

- Land application has a great potential for organic matter and phenol assimilation and they can be effectively used for OMW detoxification;

- OMW can efficiently contribute to the long-term increase in soil organic matter and nutrients (particularly P) which is of great importance for the Mediterranean olive-oil producing countries where soils have relatively low organic matter content and prone to progressive degradation;

- Enhancement of soil fertility resulting from OMW application can sustain eucalyptus trees and provide remarkable biomass yield. This yield, however, may be negatively affected by low inorganic $\mathrm{N}$ availability in the soil and/or possible toxicity phenomena in the early growth stages of vegetation;

- The organic matter and phenols concentrations in the soil appear to be affected by their initial contents in the applied OMW. This suggests the application of appropriate strategies before the OMW application in the field to reduce organic matter and phenols loadings;

- Further work is needed to elucidate: (i) the potential effects on physical properties of soil; and (ii) the potential effect of OMW and vegetation on microbial community and activity involved in critical processes in the soil, particularly those included in $\mathrm{C}$ and $\mathrm{N}$ cycling and phenol degradation.

\section{Acknowledgments}

This study was sponsored by the Greek General Secretariat for Research and Technology. The authors would like to acknowledge the critical contribution of Nikolaos V. Paranychianakis throughout the preparation of this study.

\section{Author Contributions}

Iosif Kapellakis performed the experimental work, made the data collection and analysis, and contributed to preparation of the manuscript; Vasileios A. Tzanakakis contributed to data analysis and preparation of the manuscript; and Andreas N. Angelakis had the original idea and supervised the research.

\section{Conflicts of Interest}

The authors declare no conflict of interest.

\section{References}

1. Nassar, N.N.; Arar, L.A.; Marei, N.N.; Abu Ghanim, M.M.; Dwekat, M.S.; Sawalha, S.H. Treatment of olive mill based wastewater by means of magnetic nanoparticles: Decolourization, dephenolization and COD removal. Environ. Nanotechnol. Monit. Manag. 2014, 1-2, 14-23. 
2. Kavvadias, V.; Doula, M.K.; Komnitsas, K.; Liakopoulou, N. Disposal of olive oil mill wastes in evaporation ponds: Effects on soil properties. J. Hazard. Mater. 2010, 182, 144-155.

3. Sierra, J.; Martí, E.; Garau, M.A.; Cruañas, R. Effects of the agronomic use of olive oil mill wastewater: Field experiment. Sci. Total Environ. 2007, 378, 90-94.

4. Saadi, I.; Laor, Y.; Raviv, M.; Medina, S. Land spreading of olive mill wastewater: Effects on soil microbial activity and potential phytotoxicity. Chemosphere 2007, 66, 75-83.

5. Casa, R.; D’Annibale, A.; Pieruccetti, F.; Stazi, S.R.; Giovannozzi Sermanni, G.; Lo Cascio, B. Reduction of the phenolic components in olive-mill wastewater by an enzymatic treatment and its impact on durum wheat (Triticum durum Desf.) germinability. Chemosphere 2003, 50, 959-966.

6. Cabrera, F.; López, R.; Martinez-Bordiú, A.; Dupuy de Lome, E.; Murillo, J.M. Land treatment of olive oil mill wastewater. Int. Biodeterior. Biodegrad. 1996, 38, 215-225.

7. Mekki, A.; Dhouib, A.; Sayadi, S. Changes in microbial and soil properties following amendment with treated and untreated olive mill wastewater. Microbiol. Res. 2006, 161, 93-101.

8. Piotrowska, A.; Iamarino, G.; Rao, M.A.; Gianfreda, L. Short-term effects of olive mill waste water (OMW) on chemical and biochemical properties of a semiarid Mediterranean soil. Soil Biol. Biochem. 2006, 38, 600-610.

9. Dungait, J.A.J.; Hopkins, D.W.; Gregory, A.S.; Whitmore, A.P. Soil organic matter turnover is governed by accessibility not recalcitrance. Glob. Change Biol. 2012, 18, 1781-1796.

10. Von Lützow, M.; Kögel-Knabner, I.; Ludwig, B.; Matzner, E.; Flessa, H.; Ekschmitt, K.; Guggenberger, G.; Marschner, B.; Kalbitz, K. Stabilization mechanisms of organic matter in four temperate soils: Development and application of a conceptual model. J. Plant Nutr. Soil Sci. 2008, 171, 111-124.

11. López-Piñeiro, A.; Albarrán, A.; Rato Nunes, J.M.; Peña, D.; Cabrera, D. Long-term impacts of de-oiled two-phase olive mill waste on soil chemical properties, enzyme activities and productivity in an olive grove. Soil Tillage Res. 2011, 114, 175-182.

12. Chartzoulakis, K.; Psarras, G.; Moutsopoulou, M.; Stefanoudaki, E. Application of olive mill wastewater to a Cretan olive orchard: Effects on soil properties, plant performance and the environment. Agric. Ecosyst. Environ. 2010, 138, 293-298.

13. Bodini, S.F.; Cicalini, A.R.; Santori, F. Rhizosphere dynamics during phytoremediation of olive mill wastewater. Bioresour. Technol. 2011, 102, 4383-4389.

14. Gamba, C.; Piovanelli, C.; Papini, R.; Pezzarossa, B.; Ceccarini, L.; Bonari, E. Soil microbial characteristics and mineral nitrogen availability as affected by olive oil waste water applied to cultivated soil. Commun. Soil Sci. Plant Anal. 2005, 36, 937-950.

15. Karpouzas, D.G.; Rousidou, C.; Papadopoulou, K.K.; Bekris, F.; Zervakis, G.I.; Singh, B.K.; Ehaliotis, C. Effect of continuous olive mill wastewater applications, in the presence and absence of nitrogen fertilization, on the structure of rhizosphere-soil fungal communities. FEMS Microbiol. Ecol. 2009, 70, 388-401.

16. Barbera, A.C.; Maucieri, C.; Cavallaro, V.; Ioppolo, A.; Spagna, G. Effects of spreading olive mill wastewater on soil properties and crops, a review. Agric. Water Manag. 2013, 119, 43-53.

17. Mahmoud, M.; Janssen, M.; Haboub, N.; Nassour, A.; Lennartz, B. The impact of olive mill wastewater application on flow and transport properties in soils. Soil Tillage Res. 2010, 107, 36-41. 
18. Mahmoud, M.; Janssen, M.; Peth, S.; Horn, R.; Lennartz, B. Long-term impact of irrigation with olive mill wastewater on aggregate properties in the top soil. Soil Tillage Res. 2012, 124, 24-31.

19. Osanai, Y.; Flittner, A.; Janes, J.; Theobald, P.; Pendall, E.; Newton, P.D.; Hovenden, M. Decomposition and nitrogen transformation rates in a temperate grassland vary among co-occurring plant species. Plant Soil 2012, 350, 365-378.

20. Vesterdal, L.; Elberling, B.; Christiansen, J.R.; Callesen, I.; Schmidt, I.K. Soil respiration and rates of soil carbon turnover differ among six common European tree species. Forest Ecol. Manag. 2012, 264, 185-196.

21. Haichar, F.E.Z.; Santaella, C.; Heulin, T.; Achouak, W. Root exudates mediated interactions belowground. Soil Biol. Biochem. 2014, 77, 69-80.

22. Shi, S.; Richardson, A.E.; O’Callaghan, M.; DeAngelis, K.M.; Jones, E.E.; Stewart, A.; Firestone, M.K.; Condron, L.M. Effects of selected root exudate components on soil bacterial communities. FEMS Microbiol. Ecol. 2011, 77, 600-610.

23. Paranychianakis, N.; Angelakis, A.; Leverenz, H.; Tchobanoglous, G. Treatment of wastewater with slow rate systems: A review of treatment processes and plant functions. Crit. Reviews Environ. Sci. Technol. 2006, 36, 187-259.

24. Reed, S.C.; Crites, R.W.; Middlebrooks, E.J. Natural Systems for Waste Management and Treatment; McGraw-Hill, Inc.: New York, NY, USA, 1995.

25. Swennenhuis, J. CROPWAT 8.0.; Water Resources Development and Management Service of FAO: Rome, Italy, 2009.

26. Apha, A. Standard Methods for the Examination of Water and Wastewater, 19th ed.; American Public Health Association: Washington, DC, USA, 1995.

27. García García, I.; Jiménez Peña, P.R.; Bonilla Venceslada, J.L.; Martín Martín, A.; Martín Santos, M.A.; Ramos Gómez, E. Removal of phenol compounds from olive mill wastewater using Phanerochaete chrysosporium, Aspergillus niger, Aspergillus terreus and Geotrichum candidum. Process Biochem. 2000, 35, 751-758.

28. Page, A.L. Methods of Soil Analysis. Part 2. Chemical and Microbiological Properties; American Society of Agronomy, Soil Science Society of America: Madison, WI, USA, 1982.

29. Statistics, I.S., Ed. SPSS Version 21.0 for Microsoft Windows Platform; SPSS Inc.: Chicago, IL, USA, 2012.

30. Millán, B.; Lucas, R.; Robles, A.; García, T.; Alvarez de Cienfuegos, G.; Gálvez, A. A study on the microbiota from olive-mill wastewater (OMW) disposal lagoons, with emphasis on filamentous fungi and their biodegradative potential. Microbiol. Res. 2000, 155, 143-147.

31. Robles, A.; Lucas, R.; de Cienfuegos, G.A.; Gálvez, A. Biomass production and detoxification of wastewaters from the olive oil industry by strains of Penicillium isolated from wastewater disposal ponds. Bioresour. Technol. 2000, 74, 217-221.

32. Cecchi, A.; Koskinen, W.; Cheng, H.H.; Haider, K. Sorption-desorption of phenolic acids as affected by soil properties. Biol. Fertil. Soils 2004, 39, 235-242.

33. Karpouzas, D.G.; Ntougias, S.; Iskidou, E.; Rousidou, C.; Papadopoulou, K.K.; Zervakis, G.I.; Ehaliotis, C. Olive mill wastewater affects the structure of soil bacterial communities. Appl. Soil Ecol. 2010, 45, 101-111. 
34. Tsiknia, M.; Tzanakakis, V.; Oikonomidis, D.; Paranychianakis, N.; Nikolaidis, N. Effects of olive mill wastewater on soil carbon and nitrogen cycling. Appl. Microbiol. Biotechnol. 2014, 98, 2739-2749.

35. Tzanakakis, V.A.; Paranychianakis, N.V.; Londra, P.A.; Angelakis, A.N. Effluent application to the land: Changes in soil properties and treatment potential. Ecol. Eng. 2011, 37, 1757-1764.

36. Rietz, D.N.; Haynes, R.J. Effects of irrigation-induced salinity and sodicity on soil microbial activity. Soil Biol. Biochem. 2003, 35, 845-854.

37. Setia, R.; Marschner, P.; Baldock, J.; Chittleborough, D.; Smith, P.; Smith, J. Salinity effects on carbon mineralization in soils of varying texture. Soil Biol. Biochem. 2011, 43, 1908-1916.

38. Wichern, J.; Wichern, F.; Joergensen, R.G. Impact of salinity on soil microbial communities and the decomposition of maize in acidic soils. Geoderma 2006, 137, 100-108.

39. Mohamed, D.J.; Martiny, J.B.H. Patterns of fungal diversity and composition along a salinity gradient. ISME J. 2011, 5, 379-388.

40. Guo, L.B.; Sims, R.E. H.; Horne, D.J. Biomass production and nutrient cycling in Eucalyptus short rotation energy forests in New Zealand. I: Biomass and nutrient accumulation. Bioresour. Technol. 2002, 85, 273-283.

41. Singh, G.; Bhati, M. Growth, biomass production, and nutrient composition of eucalyptus seedlings irrigated with municipal effluent in loamy sand soil of Indian desert. J. Plant Nutr. 2003, 26, 2469-2488.

42. Shah, F.U.R.; Ahmad, N.; Masood, K.R.; Peralta-Videa, J.R.; Zahid, D.M.; Zubair, M. Growth, biomass production, and nutrient composition of eucalyptus seedlings irrigated with municipal effluent in loamy sand soil of Indian desert. Int. J. Phytoremed. 2010, 12, 343-357.

43. Tzanakakis, V.A.; Paranychianakis, N.V.; Angelakis, A.N. Nutrient removal and biomass production in land treatment systems receiving domestic effluent. Ecol. Eng. 2009, 35, 1485-1492.

44. Ucisik, A.S.; Trapp, S. Uptake, removal, accumulation, and phytotoxicity of phenol in willow trees (Salix viminalis). Environ. Toxicol. Chem. 2006, 25, 2455-2460.

(C) 2015 by the authors; licensee MDPI, Basel, Switzerland. This article is an open access article distributed under the terms and conditions of the Creative Commons Attribution license (http://creativecommons.org/licenses/by/4.0/). 